\title{
Analysis of the Studies Concerning Flipped Learning Model: A Comparative Meta-Synthesis Study
}

\section{İshak Kozikoğlu}

Asst. Prof., Van Yüzüncü Y1l University, Turkey, ishakkozikoglu@hotmail.com

\begin{abstract}
The purpose of this research is to analyze the studies conducted in Turkey and abroad concerning flipped learning model from various perspectives. Eighty studies were included in this research consisting of 34 studies in Turkey and 46 studies abroad. The studies examined within the scope of this research were reached using various databases. The studies were analyzed by using content analysis technique. As a result of the research, it was concluded that the number of studies about flipped learning model have increased in recent years, the majority of the studies are article, the mostly preferred method and design are mixed method and experimental design, teaching practices were mostly carried out with the university students, the achievement test, interview form and survey were mostly used in the studies, the videos, presentations and written documents were used in out-of-class activities and practical activities were conducted in class. According to the study results, it is seen that flipped learning model has a positive effect on the students' academic achievement, motivation, metacognitive awareness, etc. Moreover, it was determined that students and teachers have positive views on flipped learning model.
\end{abstract}

Keywords: flipped learning, content analysis, meta-synthesis, studies in Turkey, studies abroad

\section{INTRODUCTION}

In recent years, educators have sought a variety of attempts to make learning more effective and permanent with the technological developments in education and differentiation of learners' characteristics and educational expectations significantly. This led to the questioning of teachers' and students' roles in education, which in turn provided the development of teaching-learning approaches, models and methods in which the student is active in the learning process and learning is not limited to the classroom environment.

Online learning has gained considerable importance in recent years. There are a variety of pedagogical models in the literature that facilitate online learning. In some of these

Citation: Kozikoğlu, İ. (2019). Analysis of the Studies Concerning Flipped Learning Model: A Comparative Meta-Synthesis Study. International Journal of Instruction, 12(1), 851-868. https://doi.org/10.29333/iji.2019.12155a 
models, courses are only processed online, so there is no face-to-face interaction. Blended learning is a broad concept that encompasses many models and points to the learning models in which more than one communication channel is used. In blended learning, there are many pedagogical approaches such as student-centered learning, active learning and problem-based learning (Murray, Koziniec and McGill, 2015). Flipped learning is seen as one of the learning models in blended learning. Flipped learning model, which requires the students to learn the content with learning materials such as video before the course and conduct related activities in the classroom, has been widely used in various disciplines in recent years (Üğ̈̈ten and Balc1, 2017).

\section{Flipped Learning Model}

There is a need for a learning model which provides student-centered, rich learning experiences that enable all students to use the most efficient time allocated for teaching. Flipped learning is a quite new learning model that supports such learning (Egbert, Herman and Lee, 2015). The concept of flipped learning was first proposed by Bergmann and Sams. In 2007, Bergmann and Sams, who worked as chemistry teachers in a high school in Colorado, USA, recorded their courses for the students who missed the courses. So, the students were able to review the content of the course by watching the videos out of class. Bergmann and Sams got effective results with this model, therefore they expanded it further by making online videos. In this model, the students learn the content of the course by watching the video before the class, therefore this model saves more time for classroom discussions and practices that enable the students to learn more deeply (Bergmann and Sams, 2012; Strayer, 2012; Tucker, 2012). Along with the different practices of the model, flipped learning model has started to be heard by the Khan Academy (https://www.khanacademy.org/) established by Salman Khan, where thousands of educational videos have been prepared and published in many fields of education (Kardaş and Yeşilyaprak, 2015).

There are various definitions of flipped learning in the literature. For example; Murray, Koziniec and McGill (2015) described flipped learning as a "learning approach in which students learn basic knowledge through short videos at home and come to the classroom environment to understand the situations that they have difficulty in learning and correct misunderstandings." Likewise, Stone (2012) defined as "the learning model in which the students watch related videos before the course and spend course time to learn the complex issues, answer the questions and establish connections with everyday life situations", Gopalan and Klann (2017) defined as "a blended educational model that allows student-centered learning in the classroom by moving teacher-guided learning out of the classroom." In this model, the videos function not only as a means of transmission of the course content to the students but also as a digital learning platform (Knight, 2016). According to some educators, pre-class activities should not be limited to internet and video, similar objectives can be achieved by appropriate learning materials and guidance (Kim, Kim, Khera and Getman, 2014). In this case, flipped learning can be defined as a learning model in which the students learn the course's content by using video, presentation, written documents, etc. benefiting from the technological opportunities before the course, and learn more deeply in the classroom by the help of 
discussion, question-answer and practical activities through the reinforcement, questioning and application of the background knowledge.

In flipped learning model, students spend more time in interactive classroom activities such as discussion, group work and project based learning because they work at home through learning materials such as videos, lecture notes, etc. (Murray, Koziniec and McGill, 2015). Unlike existing approaches in education, flipped learning model emerges as an alternative model in that it takes place the learning outside of the classroom and increases in-class interaction, at the same time. In this case, it can be concluded that flipped learning model benefits both from the benefits of out-of-school learning and face-to-face interaction.

Flipped learning has been recognized as an innovative and effective learning model among educators. In recent years, the concept of education has changed from teachercentered teaching to a student-centered learning approach. In such a change, the role of the teacher is not only to provide information but also to facilitate the active construction of the learner's knowledge. In this respect, flipped learning model aims to get the students to apply their knowledge and improve higher order thinking skills. In the traditional approach, teachers spend most of their time allocated for teaching by providing knowledge to the students and taking notes by students. Therefore, teachers do not have time for practice. On the other hand, flipped learning model, which provides flexible learning with technology, reverses teacher-student roles both inside and outside of the classroom. In flipped learning, the role of the teacher is to guide the students' thoughts and discussions, while the role of the student is to actively participate in the activities by the help of teacher guidance. Flipped learning suggests that the content should be obtained by the student's self-learning before the class in order to allow teacher-student interaction in the classroom. Therefore, more time are allowed to the teacher in order to guide the learning activities of the students and solve their problems (Ercan-Demirel, 2016; Hwang, Lai and Wang, 2015; Slomanson, 2014). Hence, flipped learning model facilitates learning in the classroom with the use of technology outside of the classroom and allows for increased teacher-student interaction in the class. By moving the teaching time out of classroom under the student responsibility, flipped learning model gains time to the teacher for dealing with students individually and practice in the classroom.

Flipped learning is applied at primary, secondary, high school and higher education levels. In this model, pre-prepared video tutorials are used to increase the effectiveness of face-to-face classroom activities (Yoshida, 2016). In other words, in the flipped learning model, out-of-class learning facilitates the acquisition of lower order thinking skills (terms, definitions, concepts, basic learning, etc.) and in-class activities facilitate the acquisition of higher order thinking skills (criticize, questioning, applying, analysis, synthesis, etc.) (Sarawagi, 2013). The Flipped Learning Network states that flipped learning model consists of four components that are flexible environment, learning culture, intentional content and professional educators (Flipped Learning Network, 2014). The flexible environment is the practice of various teaching and learning approaches to meet the interests, needs and expectations of the students. Learning 
culture refers to the transition from a teacher-centered approach to a student-centered approach in which the student is active in the process. The intentional content draws attention not only to the preference of the teacher, but also to the role of the teacher in researching and preparing the contents for the needs of the learners. The component of professional educators emphasizes the need for professional and skilled teachers in order to apply flipped learning model who observe how learners learn and who can guide them by providing the necessary feedback (Alharbi, 2015).

From the explanations above, it can be concluded that the flipped learning model is an alternative learning model in terms of both making the teaching more enjoyable and enabling effective and permanent learning by allowing practical activities. In fact, the increase in the number of studies concerning flipped learning model both in Turkey and abroad in recent years shows that it takes interest by educators and practitioners. When studies conducted abroad are examined, three articles have been reached about determining the trends in flipped learning studies. One of these was conducted by Huber and Werner (2016). This study examined 58 studies on flipped learning model applied in different disciplines in higher education and found that positive attitudes toward flipped learning practices are more evident and the students' attendance, achievement, self-efficacy perceptions increased with flipped learning model. Another one was conducted by Margulieux, McCracken and Catrambone (2015). In this study, 21 studies using flipped learning model were analyzed and it was concluded that student achievement was increased by flipped learning in majority of the studies. Another study was conducted by Rahman, Aris, Mohamed and Zaid (2014). In this study, 17 studies on flipped learning model were included in the meta-analysis and it was determined that flipped learning model has a positive effect on student achievement.

When studies conducted in Turkey are examined, it has been reached an article and a paper on determining the trends in flipped learning model. In the article conducted by Uzunboylu and Karagözlü (2017), 65 articles about flipped learning model conducted in Turkey and abroad between the years 2010 and 2015 were analyzed in terms of publication year, country, study group, method, research design, subject area and data collection tools. As a result of the research; it was determined that the number of studies on flipped learning model has increased in recent years, flipped learning model has been applied in 48 different subject areas and mostly conducted with university students, the most used research design is experimental design, the most used method is qualitative research method and mostly used data collection tools are survey and achievement test. In that study, the articles included in the analysis were only examined methodologically, so it does not provide data concerning the results of the studies. The other study was conducted by Tutal and Yazar (2017), and 52 empirical studies carried out in Turkey and abroad on flipped learning model were analyzed by using meta-analysis. In that study, it was concluded that flipped learning has a moderate and positive effect on the academic achievement of the students compared to the traditional method. In that study, only the findings of experimental studies were analyzed statistically and the number of studies left out of analysis was high. In addition, that study is limited to examining the effect of flipped learning model on academic achievement of students and therefore indepth analysis is limited. It has not been reached any comprehensive meta-synthesis 
study in the literature examining the studies on flipped learning conducted in Turkey and abroad in terms of methodology and research results, so there is a need for a comprehensive study synthesizing the trends, research methods, practices and research results on flipped learning model.

\section{Aim and Importance of the Study}

The purpose of this study is to deeply analyze the studies conducted in Turkey and abroad concerning flipped learning model in terms of publication year, publication type, research method, design, target population, data collection tools, teaching practices (content subject/discipline, duration of application, activities, etc.) and research results.

In this study, meta-synthesis, known as the thematic content analysis, was used. Content analysis studies can be generally divided into three that are meta-analysis, descriptive content analysis and meta-synthesis. In meta-analysis studies, only the findings of experimental studies are analyzed statistically and the number of studies, which do not meet the meta-analysis criteria and therefore are left out of analysis, may be high. In descriptive content analysis studies, the number of studies studied in a specific subject area must be high, and therefore, in-depth analysis and synthesis are limited. In the meta-synthesis studies, a limited number of studies on a specific subject area are described in terms of similarities and differences, synthesized with a critical perspective and discussed in depth with the results of the studies (Çalık and Sözbilir, 2014). There is a need for in-depth analysis of the studies in Turkey and abroad on flipped learning model. In this case, meta-synthesis is considered to be the most proper method for this study in order to determine the overall trends and it is aimed to synthesize all the studies on flipped learning (excluding theoretical studies) by in-depth analysis of the studies' results. When the literature were examined, it has not been reached any comprehensive meta-synthesis study in the literature examining the studies on flipped learning conducted in Turkey and abroad in terms of methodology and research results, so this study has importance in terms of meeting the needs in target literature.

\section{METHOD}

\section{Research Model}

This research is a meta-synthesis study which is one of the content analysis methods and known as thematic content analysis. In meta-synthesis studies, it is aimed to integrate the results of similar studies conducted in the same subject with a qualitative understanding (Çalık and Sözbilir, 2014; Walsh and Downe, 2005). In addition, meta-synthesis studies consist of the stages that are identification of similar studies in the same subject, determination of the criteria for the studies to be included in the research, methodological comparison of the studies and integration of the research results (Sandelowski, Docherty and Emden, 1997). As it is aimed to analyze the studies conducted in Turkey and abroad concerning flipped learning model in terms of methodology and research results, it is thought that meta-synthesis is proper for the purpose of this study. 


\section{Study Population}

The studies examined within the scope of this study were reached using the databases such as Google Academic, COHE National Dissertation Center, ULAKBIM, DergiPark, Sobiad, ProQuest, ERIC, EBSCO, SPRINGER. In selection of the studies to be included in the research, the criteria were determined as "being an empirical study (experimental, survey, etc.)", "being thesis, article or paper", and the studies that meet these criteria were included in the study. Theoretical studies and content analysis studies (meta-analysis, descriptive content analysis, and meta-synthesis) related to the flipped learning model were not included in the study. In this respect, this study was conducted on the data obtained from totally 80 studies consisting of 34 studies in Turkey and 46 studies abroad.

\section{Data Analysis}

In this study, research data were analyzed with content analysis as one of the qualitative data analysis techniques. Content analysis is used in the analysis of communication examples and written materials such as interviews, diaries and documents (Fraenkel, Wallen and Hyun, 2012; Patton, 2002). A content analysis form was prepared by the researcher using the Microsoft Office Excel Program to analyze the studies included in the research. In preparing the content analysis form; the themes were determined as publication year, publication type, research method, design, target population, data collection tools, teaching practices (content subject/discipline, duration of application, activities, etc.) and research results.

Coding Process: In this study, the following steps were followed during the coding of the data according to the determined themes:

1. Each study included in this research was examined in detail within the framework of the determined themes, codes for each theme were determined and these codes were transferred to the computer.

2. The data obtained from the studies examined within the scope of this research were presented according to the determined themes and codes. In addition, similarities and differences in research methods and results of the studies were pointed out.

Validity and Reliability: In order to increase external reliability in this study, the position of the researcher and detailed explanations of the studies examined within the scope this research were presented. In order to provide internal reliability, half of the studies examined in this research (40 studies) were coded separately by two different coders, the percentage of correspondence between two coders was calculated by using the formula proposed by Miles and Huberman (1994) (Reliability= number of agreements/total number of agreements + disagreements), and it was found to be $94 \%$. Thus, it can be said that the coding is sufficiently reliable (Miles and Huberman, 1994). In this study, in order to ensure internal validity, the integrity and consistency of the data obtained from the studies were constantly reviewed; and detailed explanations were made about the processes such as determination of the study population, coding and analysis of the data in order to provide external validity. 


\section{FINDINGS}

In this section, the results concerning the studies examined in the scope of this research are presented in terms of publication year, publication type, research method, design, target population, data collection tools, teaching practices (content subject/discipline, duration of application, activities, etc.) and research results.

\section{Publication Year and Type}

When studies concerning flipped learning model conducted in Turkey were examined, it was found that there is no study before 2014, and only one study in 2014 has been reached. There are nine studies in 2015, 16 studies in 2016 and eight studies in 2017. When studies conducted abroad were examined, it was found that there are one article for each in 2002, 2006 and 2009, two articles in 2010, one article and one PhD thesis in 2012, nine studies in 2013, 10 studies in 2014, 11 studies in 2015, eight studies in 2016, one study in 2017. Therefore, it seems that there has been a significant increase in recent years in the number of studies on flipped learning both in Turkey and abroad. The studies examined in the scope of this research are mostly article $(45 ; \% 56)$, master thesis $(19 ; \% 24), \mathrm{PhD}$ thesis $(14 ; \% 18)$ and paper $(2 ; \% 2)$, respectively.

\section{Research Method and Design}

It was found that mixed method was used in more than half of the studies on flipped learning $(42,53 \%)$ and in some studies quantitative $(29,36 \%)$ and qualitative $(9,12 \%)$ methods were used, respectively. It was determined that experimental design was mostly used in the studies $(57,78 \%)$; and survey (10), case study (7), action research (3) and phenomenological design (2) were used in some studies.

\section{Target Population of the Studies}

In the studies examined in this research, it was found that flipped learning model was applied in different sample or study groups. Most of the studies in Turkey on flipped learning $(25,74 \%)$ were conducted with university students. 14 of these studies were conducted with prospective teachers in Faculty of Education, 11 of them were conducted with university students in other faculties. In addition, four studies were conducted with high school students, four studies were conducted with secondary school students and one study was conducted with teachers.

Similarly, most of the studies abroad on flipped learning $(31,67 \%)$ were conducted with university students. In addition, 11 studies were conducted with secondary school students, seven studies with teachers, six studies with high school students, and one study with primary school students. In this case, it is seen that, in 10 studies conducted abroad, data were collected from more than one target group (eg. both students and teachers).

\section{Data Collection Tools}

It was found that interview forms $(25 ; 74 \%)$ and achievement test $(22 ; 65 \%)$ were used in majority of the studies conducted in Turkey. Following the interview form and 
achievement test, it was found out that scale (14), survey (8), inventory (2), observation form (2), various tests (1) and document analysis (1) were mostly used in the studies, respectively. On the other hand, in the studies conducted abroad it was found that achievement test $(31 ; 67 \%)$ and survey $(27 ; 59 \%)$ were mostly used. Following the achievement test and survey, it was found out that interview form (17), observation form (6), scale (4), various tests (2) and dairy (2) were mostly used in the studies, respectively.

\section{Differences and Similarities Concerning Teaching Practices}

In the studies examined within the scope of this research, it is seen that flipped learning model was applied in different disciplines. It was found that most of the flipped learning practices conducted in Turkey were conducted in English course $(11,32 \%)$ and in courses (programming, computer, web editor, information technologies) concerning Information Technologies $(8,24 \%)$, respectively. It is also seen that the effectiveness of flipped learning practices in teacher education, medical education, fine arts courses and in various numerical and verbal courses were examined.

Most of the flipped learning practices conducted abroad were conducted in Mathematics (12, 26\%), courses (science education, biology, chemistry) concerning Science Education $(7,15 \%)$ and in courses (information and communication technologies, educational technologies, programming, etc.) concerning Information Technologies (7, $15 \%)$, respectively. In addition, it is seen that studies conducted abroad have examined the effectiveness of flipped learning practices in English, business administration, health sciences, social sciences, psychology and engineering-architecture courses.

Since there is no access to the contents of some of the studies examined in this research, detailed information about the practices (time, activities, etc.) could not be reached and the duration or details of the teaching practices were not specified in some studies. In the studies conducted in Turkey (22) in which the duration of the practices was specified; it was found that the teaching based on flipped learning model was carried out "between 4-7 weeks" in six studies, "8 weeks" in six studies and "10 weeks and over" in ten studies. In this case, it is seen that in most of the studies conducted in Turkey, the teaching based on flipped learning model was carried out at least eight weeks. When the studies abroad are examined, in the studies conducted abroad (31) in which the duration of the practices was specified; it was found that the teaching based on flipped learning model was carried out "between 4-7 weeks" in four studies, "8-9 weeks" in five studies and "10 weeks and over" in 22 studies. In this case, it is seen that in most of the studies conducted abroad, the teaching based on flipped learning model was carried out mostly 10 weeks and over.

In the studies conducted in Turkey and abroad examined within the scope of this research, it is observed that in-class and extracurricular activities are carried out in accordance with flipped learning model. It is seen that various sharing/learning platforms were used in most of the studies such as website/online forum, Facebook, Edpuzzle, Moodle and Edmodo in order to share the materials prepared for extracurricular activities and to provide quick interaction with the students. In the 
studies, it is seen that, within the scope of extracurricular activities, teaching materials such as videos, quizzes/homework, attendance sheets/written documents, presentation files and audio files were mostly shared with the students. It is aimed that the students learn the content of the course theoretically before the course through extracurricular teaching materials. In the studies, it is seen that, within the scope of in-class activities, practical activities were conducted such as summarizing the topic, questionanswer/discussion, exercise, demonstration, group work and problem based learning. It is aimed that the students discuss the topics and apply activities related to the topic through in-class activities.

\section{Research Results of the Studies}

It was found that the studies conducted abroad and in Turkey on flipped learning model reached similar results. According to the results of the studies conducted in Turkey, it is seen that flipped learning model has a positive effect on the students' academic achievement, motivation, meta-cognitive awareness, self-learning ability, attitudes and retention of learning. It was found that flipped learning model reduces the level of homework/ task stress and anxiety. On the other hand, in one study, it was found that there is no significant difference between the experimental and control groups in terms of readiness for self-directed learning and self-efficacy perceptions, while in one study it was found that there is a significant difference on behalf of experimental group (flipped learning model). In two studies, it was determined that there is no significant difference between the experimental and control groups in terms of academic achievement scores. In addition, in one each of the studies, it was found that flipped learning model does not make a significant difference on students' epistemological beliefs, transfer of learning, mental risk taking skills, computer thinking skills and learner autonomy scores.

Similarly, according to the study results conducted abroad, it is seen that the flipped learning model has a positive effect on the students' academic success, attitudes, selfefficacy perceptions, critical thinking skills and information literacy. On the other hand, in seven studies, it was determined that there is no significant difference between the experimental and control groups in terms of academic achievement scores.

In addition, it was determined that students and teachers have positive views on flipped learning model in the studies conducted in Turkey and abroad. It was found that teachers and students stated positive aspects of flipped learning model as enabling active participation of the students, providing effective and permanent learning, enhancing motivation, providing a fun and positive classroom environment, ensuring flexible and self-paced learning, increasing classroom interaction (sharing), increasing students' responsibility, developing students' higher order thinking skills, providing students with ready access to learning materials, providing students with self-confidence, reducing anxiety.

\section{DISCUSSION AND CONCLUSION}

In this section, the discussion and conclusion concerning the themes are presented respectively. 


\section{Discussion and Conclusion Concerning Publication Year and Type}

As a result of this study, it was determined that there has been a significant increase in the number of studies on flipped learning conducted in Turkey and abroad in recent years. Similarly, in the study by Uzunboylu and Karagözlü (2017) on analyzing 65 studies concerning flipped learning conducted in Turkey and abroad, it was found that there has been a significant increase in the number of studies on flipped learning in recent years. As a matter of fact, it is emphasized in the literature that flipped learning has been widely used in recent years and is accepted as an innovative and effective teaching approach among educators (Caicco, 2016; Ercan-Demirel, 2016; Hwang, Lai and Wang, 2015; Slomanson, 2014; Üğ̈̈ten and Balc1, 2017). In this case, it can be said that in recent years there has been an interest in flipped learning model both in Turkey and around the world, and the number of empirical studies related to this model has increased. It can be said that technological developments in education and differentiation of learners' characteristics, educational expectations significantly in recent years have encouraged the educators for the flipped learning model which provides both online learning and face-to-face interaction by moving the learning out of the classroom environment. Furthermore, when comparing the empirical studies related to this model in Turkey and abroad, it is seen that the first study in Turkey is in 2014 while it dates back to the year 2002 abroad. In this case, it can be said that the studies related to flipped learning started earlier abroad compared to Turkey.

Furthermore, it was determined that more than half of the studies examined within the scope of this research are article, almost the other half of the studies are conducted as master thesis, $\mathrm{PhD}$ thesis and paper. In this case, it seems that more $\mathrm{PhD}$ thesis on flipped learning need to be prepared in order to get more comprehensive and in-depth coverage of the practices on flipped learning model.

\section{Discussion and Conclusion Concerning Research Method and Design}

As a result of this study, it was determined that mixed method is preferred in most of the studies on flipped learning. Unlike this study, in the study conducted by Uzunboylu and Karagözlü (2017) on flipped learning model, it was found that qualitative research method was mostly used in the articles. The fact that nearly one out of five studies examined within the scope of this research are thesis studies may be effective on the preference of the mixed method in the studies. As a matter of fact, it is emphasized that in the field of education, the use of mixed method has increased in the thesis studies in recent years (B1kmaz, Aksoy, Tatar and Altınyüzük, 2013; Kozikoğlu and Senemoğlu, 2016). As mixed method studies provide a better understanding of the research problems and questions compared to the studies using single method by combining the weakness of one method with the strength of the other method (Creswell, 2014), the use of mixed method in the studies examined within the scope of this research can be regarded as a positive result.

Furthermore, it was determined that experimental design was mostly used as a research design in the studies. Similarly, in the study conducted by Uzunboylu and Karagözlü (2017) on flipped learning model, it was determined that experimental design was 
mostly used in the studies. The emergence of technological developments in the field of education and student-centered learning models and approaches have increased the use of experimental design in order to scientifically demonstrate the effectiveness of these approaches compared to traditional approaches (Ross and Morrison, 1996). In this respect, in most of the studies examined in this research, it can be said that the examination of the flipped learning model's effect on the variables such as academic achievement, attitude, motivation, anxiety, etc. necessitates the use of experimental design.

\section{Discussion and Conclusion Concerning Target Population of the Studies}

It was concluded that most of the studies in Turkey on flipped learning were conducted with university students. Similarly, in the study conducted by Uzunboylu and Karagözlü (2017) on flipped learning model, it was concluded that most of the studies on flipped learning were conducted with university students. Although flipped learning practices can be applied at different levels such as primary school, secondary school, high school and higher education (Yoshida, 2016), the number of studies to determine the effectiveness of flipped learning practices in primary and secondary school is quite limited (Mohanty and Parida, 2016). The fact that primary and secondary school students may experience more difficulty in carrying out extracurricular activities than older age groups may have caused conducting fewer studies with them. In this case, it can be said that there is a need for applying flipped learning practices to the primary, secondary and high school classes and evaluating the results.

\section{Discussion and Conclusion Concerning Data Collection Tools}

It was determined that achievement test, interview form and survey were mostly used in the studies examined in this research. In addition, it was concluded that, apart from the interview form, survey and achievement test, data collection tools such as scale, observation form, various tests, inventory, dairy and document analysis were mostly used in the studies, respectively. As a result of the study conducted by Uzunboylu and Karagözlü (2017), it was determined that survey and achievement test were mostly used in the studies examined. Likewise, in many content analysis studies in the literature, it was concluded that scale, survey, achievement test and interview form were mostly used in the studies conducted in the field of educational sciences (B1kmaz et al., 2013; Gömleksiz and Bozpolat, 2013; Karadağ, 2011; Kozikoğlu and Senemoğlu, 2016; Ozan and Köse, 2014; Saracaloğlu and Dursun, 2010). In this case, it can be said that, in the studies conducted in Turkey and abroad on flipped learning model, achievement test and scale were mostly used in order to determine the effect of flipped learning on students' academic achievement and various variables; interview form and survey were mostly used in order to determine students' opinions and experiences on flipped learning model. This result can be related to the use of the mixed method mostly in the studies examined within the scope of this research. 


\section{Discussion and Conclusion Concerning Differences and Similarities in Teaching Practices}

As a result this study, it was concluded that, besides applied in various courses, most of the flipped learning practices in Turkey were conducted in English course and in the courses concerning Computer/Information Technologies; on the other hand, most of the flipped learning practices abroad were conducted in Mathematics, Science Education courses and in the courses concerning Computer/Information Technologies. In the study conducted by Uzunboylu and Karagözlü (2017), it was determined that flipped learning model was applied in 48 different subject areas. In this case, it can be concluded that flipped learning model is applicable in different disciplines. Technology-based practices and educational materials are extensively used in English, Mathematics, Science Education courses and the courses concerning Computer/Information Technologies. Moreover, in these courses, there is a need for practice and interaction in the classroom. Therefore, the application of flipped learning model in these courses intensively may be related to these issues.

Furthermore, it was concluded that the teaching based on flipped learning model was carried out at least eight weeks in most of the studies examined in this research. This result can be regarded as a positive situation in terms of allowing long-term interaction in experimental studies.

In the studies examined within the scope of this research, it was determined that various sharing/learning platforms were used in most of the studies such as website/online forum, Facebook, Edpuzzle, Moodle and Edmodo in order to share the materials prepared for extracurricular activities and to provide quick interaction with the students. In the studies, it was determined that, within the scope of extracurricular activities, teaching materials such as videos, quizzes/homework, attendance sheets/written documents, presentation files and audio files are mostly shared with the students. It was aimed that the students learn the content of the course theoretically before the course through extracurricular teaching materials; and they discuss the topics and apply activities related to the topic through in-class activities. Moreover, it was determined that, within the scope of in-class activities, practical activities are conducted such as summarizing the topic, question-answer/discussion, exercise, demonstration, group work, problem based learning, etc. As, in flipped learning model, it is aimed the students to learn the content of the course via video, presentation and written documents before the course and perform practical activities in the classroom (Ercan-Demirel, 2016; Gopalan and Klann, 2017; Hwang, Lai and Wang, 2015; Murray, Koziniec and McGill, 2015; Slomanson, 2014; Stone, 2012; Üğ̈̈ten and Balc1, 2017), it can be said that the practices in the studies examined within the scope of this research were carried out in accordance with the aims and principles of flipped learning model.

Different practices are implemented in flipped learning model. According to some educators, pre-class activities should not be limited to internet and video, similar objectives can be achieved by appropriate learning materials and guidance (Kim, Kim, Khera and Getman, 2014). In the study conducted by Turro, Mengod, Morales and 
Busquets (2016), flipped learning model with two different practices was compared. In one group, the practice was performed using video, while the practice was performed with the help of online course content and pdf files without using video in the other group. As a result of the research, it was determined that in the video application, the students were more active in the class and more satisfied with flipped learning model. On the other hand, in Tully's study (2014), it was found that students have a more positive attitude towards the use of various technologies such as WebQuest, virtual applications, animations, and interactive videos rather than simply using video in flipped learning model. In this case, in the studies examined within the scope of this research, the use of different learning materials in the scope of extracurricular activities such as videos at most and the use of practical activities in the scope of in-class activities can be evaluated as a positive result in terms of providing rich learning experiences for the students.

\section{Discussion and Conclusion Concerning Research Results of the Studies}

As a result of this study, according to the results obtained from the studies on flipped learning model conducted in Turkey and abroad, it was concluded that flipped learning model has a positive effect on students' academic achievement, motivation, metacognitive awareness, self-learning skills, attitude, critical thinking, information literacy and retention of learning. It was concluded that flipped learning model reduces the students' homework/task stress and anxiety levels. In the meta-analysis study of Tutal and Yazar (2017) involving 52 empirical studies conducted in Turkey and abroad concerning flipped learning model, it was concluded that flipped learning has a moderate and positive effect on the academic achievement of the students compared to traditional method. In the study conducted by Huber and Werner (2016) examining 58 studies on flipped learning model applied in different disciplines in higher education, it was concluded that active participation of learners, their achievement and self-efficacy increased in most of the studies. In the study conducted by Margulieux, McCracken and Catrambone (2015), it was concluded that students' academic achievement increased in most of 21 studies using flipped learning model. In the meta-analysis study conducted by Rahman, Aris, Mohamed and Zaid (2014) involving 17 studies on flipped learning model, it was determined that flipped learning model has a positive effect on student achievement. In this case, based on the research results both in Turkey and abroad concerning flipped learning model, it can be said that flipped learning model has a positive effect on students' academic achievement, performance, motivation, metacognitive awareness, self-learning skills, attitude, critical thinking, information literacy and retention of learning.

In the studies examined within the scope of this research, it was determined that students and teachers have positive views on flipped learning model. Similarly, in the study conducted by Huber and Werner (2016), positive perceptions towards flipped learning model were quite more. In the studies examined within the scope of this research, it was determined that teachers and students stated positive aspects of flipped learning model as enabling active participation of the students, providing effective and permanent learning, enhancing motivation, providing a fun and positive classroom environment, 
ensuring flexible and self-paced learning, increasing classroom interaction (sharing), increasing students' responsibility, developing students' higher order thinking skills, increasing students' background knowledge, providing students with ready access to learning materials, providing students with self-confidence, reducing anxiety. As a matter of fact, in the literature it is emphasized that flipped learning model has some benefits such as increasing the teacher-student and student-student interaction in the classroom, providing the student to learn at his/her individual pace, saving time for the teacher, providing the student to be ready for the class, providing fun and flexible learning, ensuring the student to access more information resources, ensuring effective learning, etc (Arnold-Garza, 2014, Bergmann and Sams, 2012; Du, Fu and Wang, 2014; Ercan-Demirel, 2016, Hwang, Lai and Wang, 2015; Neaupane, 2017; Slomanson, 2014). In this respect, it can be said that flipped learning model has various positive aspects such as providing more fun and meaningful learning, enabling active participation of the students by increasing classroom interaction, development of students' higher order thinking skills and positive affective reflections (attitude, motivation, etc.) by allowing students to progress in their own pace and review the knowledge through the videos and various learning materials.

\section{SUGGESTIONS}

Progression in social, cultural and economic fields can be realized with innovative and qualified practices in every field of education (Turkish Education Association, 2011). Flipped learning model seems to have a positive effect on the cognitive and affective objectives of the students and is known as an innovative learning model in the educational settings in recent years. It is therefore advisable to apply flipped learning model to different groups of students in different disciplines and in different levels especially in primary, secondary and high school classes and evaluate the research results. In addition, it may be advisable to use flipped learning model as an alternative in existing programs as it takes learning out of school institutions and makes learning more effective and permanent.

It is suggested to conduct more $\mathrm{PhD}$ thesis in which various data collection tools such as achievement test, observation, interview, student/teacher diaries and document analysis are used together in order to provide a more comprehensive and in-depth analysis of the practices on flipped learning model. It was determined that the studies in the literature have been conducted to examine the effect of flipped learning on the individual characteristics (achievement, attitude, motivation, etc.) of the students. Therefore, in future studies, the effect of flipped learning on variables such as classroom climate, learning environment perceptions and classroom interaction may be examined. No scale development studies have been reached concerning the evaluation of the practices on flipped learning. In this case, it may be advisable to conduct scale development studies to determine the views and experiences of students and teachers on practices concerning flipped learning model. It may be suggested that pre-service teacher education programs and in-service trainings for teachers include courses and seminars on new models, approaches and trends in education. In this way, it is possible for teachers and prospective teachers to know how to apply flipped learning model in their own 
disciplines in order to create student-centered learning environments that the constructivist approach emphasizes.

\section{REFERENCES}

Alharbi, A. H. 2015. "A Flipped Learning Approach Using Social Media In Health Informatics Education". Creative Education, 6 (13), 1466-1475.

Arnold-Garza, S. 2014. "The Flipped Classroom Teaching Model And İts Use For İnformation Literacy İnstruction". Communications in Information Literacy, 8 (1), 7.

Bergmann, J., and Sams, A. 2008. "Remixing Chemistry Class". Learning and Leading with Technology, 36 (4), 24-27.

Bergmann, J., and Sams, A. 2012. "Flip Your Classroom: Reach Every Student In Every Class Every Day". OR: International Society for Technology in Education.

B1kmaz, F. H., Aksoy, E., Tatar, Ö. ve Altınyüzük, C. A. 2013. "Eğitim Programları Ve Öğretim Alanında Yapılan Doktora Tezlerine Ait Içerik Çözümlemesi (1974-2009)". Ĕ̆itim ve Bilim Dergisi, 38 (168), 288-303.

Caicco, J. M. 2016. "Teacher Experiences With Flipped Classrooms In Secondary Science". University of Toronto, Department of Curriculum, Teaching and Learning.

Çalık, M. ve Sözbilir, M. 2014. "İçerik Analizinin Parametreleri". Eğitim ve Bilim, 39 (174), 33-38.

Du, S. C., Fu, Z. T., and Wang, Y. 2014. "The Flipped Classroom-Advantages And Challenges". In Proceedings of the 2014 International Conference on Economic Management and Trade Cooperation, 107,17-20.

Egbert, J., Herman, D., and Lee, H. 2015. "Flipped İnstruction İn English Language Teacher Education: A Design-Based Study İn A Complex, Open-Ended Learning Environment". Tesl-Ej 19 (2), 1-23.

Ercan-Demirel, E. 2016. "Basics And Key Principles Of Flipped Learning: Classes Upside Down". International Journal of Languages, Literature and Linguistics, 2 (3), 109-112.

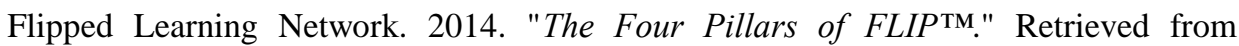
https://flippedlearning.org/wpcontent/uploads/2016/07/FLIP_handout_FNL_Web.pdf.

Fraenkel, J. R., Wallen, N. E., and Hyun, H. H. 2012. "How To Design And Evaluate Research In Education ( $8^{\text {th }}$ Edition)". USA: The McGraw-Hill Companies, Inc.

Gopalan, C., and Klann, M. C. 2017. "The Effect Of Flipped Teaching Combined With Modified Team-Based Learning On Student Performance In Physiology". Advances in Physiology Education, 41 (3), 363-367.

Gömleksiz, M. N. ve Bozpolat, E. 2013. "Eğitim Programları Ve Öğretim Alanındaki Lisansüstü Tezlerin Değerlendirilmesi". The Journal of Academic Social Science Studies ,6(7), 457-472. 
Huber, E., and Werner, A. 2016. "A Review Of The Literature On Flipping The STEM Classroom: Preliminary Findings". In S. Barker, S. Dawson, A. Pardo, and C. Colvin (Eds.), Show Me The Learning. Proceedings ASCILITE 2016 Adelaide (pp. 267-274).

Hwang, G. J., Lai, C. L., and Wang, S. Y. 2015. "Seamless Flipped Learning: A Mobile Technology-Enhanced Flipped Classroom With Effective Learning Strategies". Journal of Computers in Education, 2(4), 449-473.

Karadağ, E. 2011. "Eğitim Bilimleri Doktora Tezlerinde Kullanılan Ölçme Araçları: Nitelik Düzeyleri Ve Analitik Hata Tipleri". Kuram ve Uygulamada Eğitim Bilimleri, 11 (1), 311-334.

Kardas, F. ve Yesilyaprak, B. 2015. "A Current Approach To Education: Flipped Learning Model". Ankara Üniversitesi Eğitim Bilimleri Fakültesi Dergisi, 48(2), 103121.

Kim, M. K., Kim, S. M., Khera, O., and Getman, J. 2014. "The Experience Of Three Flipped Classrooms In An Urban University: An Exploration Of Design Principles". Internet and Higher Education 22: 37-50.

Knight, M. 2016. "Flipped Classrooms And Discovery Learning In Business And Professional Communication". Business and Professional Communication Quarterly, 79 (1), 3-5.

Kozikoğlu, İ. ve Senemoğlu, N. 2016. "Eğitim Programları Ve Öğretim Alanında Yapılan Doktora Tezlerinin Içerik Analizi (2009-2014)". Eğitim ve Bilim, 40(182), 12 24.

Margulieux, L. E., McCracken, W. M., and Catrambone, R. 2015. "Mixing In-Class And Online Learning: Content Meta-Analysis Of Outcomes For Hybrid, Blended, And Flipped Courses". In O. Lindwall, P. Hakkinen, T. Koschmann, P. Tchounikine, \& S. Ludvigsen (Eds.) Exploring the Material Conditions of Learning: The Computer Supported Collaborative Learning (CSCL) Conference (pp. 220-227).

Miles, M. B., and Huberman, A. M. 1994. "Qualitative Data Analysis (2 ${ }^{\text {nd }}$ Edition)". Thousand Oaks, CA: Sage Publications.

Mohanty, A., and Parida, D. 2016. "Exploring The Efficacy \& Suitability Of Flipped Classroom Instruction At School Level In India: A Pilot Study". Creative Education, 7 (05),768.

Murray, D., Koziniec, T., and McGill, T. J. 2015. "Student Perceptions Of Flipped Learning". In Australasian Computer Education Conference (ACE), 57-62.

Neaupane, D. 2017. "Videos Production For Flipped Classroom: A Guide For Teachers". Helsinki Metropolia University of Applied Sciences.

Ozan, C. ve Köse, E. 2014. "Eğitim Programları Ve Öğretim Alanındaki Araştırma Eğilimleri". Sakarya Üniversitesi Journal of Education, 4(1), 116-136. 
Patton, M. Q. 2002. "Qualitative Research \& Evaluation Methods ( $3^{\text {rd }}$ Edition)". USA: Sage Publications, Inc.

Rahman, A. A., Aris, B., Mohamed, H., and Zaid, N. M. 2014. "The Influences Of Flipped Classroom: A Meta Analysis". In Engineering Education (ICEED) 2014 IEEE 6th Conference on (pp. 24-28).

Ross, S. M., and Morrison, G. R. 1996. "Experimental Research Methods". Handbook Of Research For Educational Communications And Technology: A Project Of The Association For Educational Communications And Technology, 1148-1170.

Sandelowski , M., Docherty S., and Emden C. 1997. "Qualitative Metasynthesis: Issues And Techniques". Research in Nursing and Health, 20, 365-371.

Saracaloğlu, A. ve Dursun, F. 2010. "Türkiye'de Eğitim Programları Ve Öğretim Alanındaki Lisansüstü Tezlerin Incelenmesi". 1. Ulusal Ĕgitim Programlarl ve Öğretim Kongresi Tam Metinler Kitabı. Ankara: Pegem Akademi.

Sarawagi, N. 2013. "Flipping An Introductory Programming Course: Yes You Can!" Tutorial Presentation CCSC: Northeastern Conference.

Slomanson, W. R. 2014. "Blended Learning: A Flipped Classroom Experiment." Journal of Legal Education, 64 (1), 93-102.

Stone, B. B. 2012. "Flip Your Classroom To Increase Active Learning And Student Engagement". In: Proceedings From 28th Annual Conference on Distance Teaching and Learning: Madison, WI.

Strayer, J. F. 2012. "How Learning İn An İnverted Classroom İnfluences Cooperation, İnnovation And Task Orientation". Learn Environ Res, 15, 171-193.

Topalak, Ş. 2016. "Çevrilmiş Öğrenme Modelinin Başlangıç Seviyesi Piyano Ögrretimine Etkisi". Yayınlanmamış doktora tezi: İnönü Üniversitesi, Eğitim Bilimleri Enstitüsü.

Tucker, B. 2012. "The Flipped Classroom". Education Next, 12(1),13-26.

Tully, D. R. 2014. "The Effects Of A Flipped Learning Model Utilizing Varied Technology Versus The Traditional Learning Model In A High School Biology Classroom." Master thesis: Montana State Unıversity, Science Education.

Turro, C., Mengod, R., Morales, J. C., \& Busquets, J. (2016). Video is key for flipped learning: An experience at Universitat Politecnica de Valencia. In SE@VBL@ $L A K$ (pp. 18-25).

Tutal, Ö. ve Yazar, T. 2017. "Ters-Yüz Sınıf Yaklaşımının Akademik Başarıya Etkisi: Bir Meta-Analiz Çalışması". 5th International Curriculum and Instruction Congress Muğla, Türkiye.

Türk Eğitim Derneği. 2011. "Uluslararası Eğitim Forumu II: Eğitimde İnovasyon." Ankara: Türk Eğitim Derneği ve Sebit. 
Uzunboylu, H. ve Karagözlü, D. 2017. "The Emerging Trend Of The Flipped Classroom: A Content Analysis Of Published Articles Between 2010 And 2015". RED. Revista de Educación a Distancia (54).

Üğüten, S. D. ve Balc1, Ö. 2017. "Flipped Learning." Journal of Süleyman Demirel University Institute of Social Sciences, 26 (1), 253-265.

Walsh, D., and Downe, S. 2005. "Meta-Synthesis Method For Qualitative Research: A Literature Review". Journal of Advanced Nursing, 50(2), 204-211.

Yoshida, H. 2016. "Perceived Usefulness Of" Flipped Learning" On Instructional Design For Elementary And Secondary Education: With Focus On Pre-Service Teacher Education". International Journal of Information and Education Technology, 6(6), 430434. 